\title{
Erken Dönem Ekonomi Eğitimi ve Finansal Sosyalizasyonun Finansal Okuryazarlık Düzeyine Etkisi*
}

\section{Effect of Early Economy Education and Financial Socialization on Financial Literacy Level}

\author{
Dr. Öğr. Üyesi Durmuş YILDIRIM ${ }^{\left(D^{1}\right.}{ }^{1}$, Dr. Öğr. Üyesi Adem ÖZBEK ${ }^{(D)} 2$
}

\begin{abstract}
$\ddot{\mathbf{O} z}$
Bu çalışmada amaç, erken dönem ekonomi ve finans eğitimi ile finansal sosyalizasyon ajanlarının bireyin finansal okuryazarlık düzeyi ve finansal davranışları üzerindeki etkisini araştırmaktır. Bu amaç çerçevesinde Trabzon, Ordu, Samsun ve Erzincan bölgesinde 14-18 yaş aralığında olup Uluslararas1 Bakalorya (IB) eğitimi alan ve almayan özel okul öğrencileri ile Ticaret Meslek Lisesi öğrencilerinden oluşan 1274 kişilik üç farklı gruba anket uygulanmıştır. Verilerin analizinde yapısal eşitlik modeli kullanılmıştır. Analiz sonuçlarına göre Uluslararası Bakalorya Eğitimi alan öğrencilerle çocukluk dönemi finansal sosyalizasyon faktörlerinden aile geçmişi, alınan ekonomi eğitimi ve kalitesi, para ve iş üzerinden sağlanan finansal sosyalleşme ve aritmetik bilgi değişkenlerinin finansal okuryazarlık düzeyi üzerinde olumlu bir etkiye sahip olduğu tespit edilmiş ve bu öğrencilerin finansal okuryazarlık düzeylerinin finansal davranışları üzerinde pozitif bir etkisi olduğu görülmüştür. IB eğitimi almayan diğer okul öğrencilerinin finansal okuryazarlık düzeylerinin ise finansal davranışları üzerinde bir etkisinin olmadığı tespit edilmiştir.
\end{abstract}

Anahtar Kelimeler: Finansal sosyalizasyon, finansal okuryazarlık, finansal davranış, erken dönem ekonomi eğitimi, uluslararası bakalorya eğitimi

Makale Türü: Araştırma

\begin{abstract}
The aim of this study is to investigate the effects of early economic and financial education and financial socialization agents on the individual's financial literacy level and financial behavior. For this purpose, a questionnaire was applied to three different groups of 1274 students from Trabzon, Ordu, Samsun and Erzincan, between the ages of 14-18 and those who were or did not receive International Baccalaureate (IB) education, and Commercial Vocational High School students. Structural equation model was used in the analysis of the data. According to the results of the analysis, it was determined that the variables such of family history, economic education and quality financial socialization and arithmetic information provided through money and work, and the financial literacy levels of these students, has a positive effect on their financial behavior. It was determined that the financial literacy levels of other school students who did not have any education on IB have no effect on their financial behavior.
\end{abstract}

Keywords: Financial socialization, financial literacy, financial behavior, early economic education, international baccalaureate education

Paper Type: Research

\footnotetext{
* Bu çalışma, Ondokuz Mayıs Üniversitesi Sosyal Bilimler Enstitüsü'nün belirlediği jüri tarafindan 16.09.2019 tarihinde kabul edilen “Erken Dönemde Ekonomi Eğitiminin Finansal Okuryazarlık Düzeyine Etkisi: Uluslararası Bakalorya Örneği” isimli doktora tezinden türetilmiştir.

${ }^{1}$ Ondokuz Mayıs Üniversitesi, IİBF, durmus.yildirim@omu.edu.tr.

${ }^{2}$ Gümüşhane Üniversitesi, Sosyal Bilimler MYO, ademozbek@gumushane.edu.tr.
}

Atıf için (to cite): Yıldırım., D. ve Özbek., A. (2021). Erken dönem ekonomi eğitimi ve finansal sosyalizasyonun finansal okuryazarlık düzeyine etkisi, Afyon Kocatepe Üniversitesi Sosyal Bilimler Dergisi, 23(2), 694-710. 


\section{Giriş}

Dünya genelinde nerdeyse bütün ülkeler hane halklarının mali kararlarını iyileştirmek amacıyla finansal okuryazarlığı teşvik etme politikalarını desteklemektedir. Finansal okuryazarlık, kişinin finansal kavramları, finansal hizmetleri ve ürünleri anlama ve finansal durumunu planlama yeteneği olarak tanımlanır. Finansal okuryazar olan bir bireyin ise daha ihtiyatlı finansal kararlar vereceği, tüketimden çok tasarrufa yöneleceği ve ülkelerin finansal piyasalarında etkin bir rol oynayacağı varsayılmaktadır (Xu ve Zia, 2012). Ancak finansal okuryazarlık düzeyi her zaman bireyler üzerinde arzu edilen bir finansal davranışa dönüşmemektedir. Bu nedenden dolayıdır ki, son yıllarda farklı içerikleri kapsayan finansal okuryazarlık müfredatları ortaya çıkmış ve çıkmaya devam etmektedir.

Günümüz dünyasında finans, sadece ilgi alanına giren kişiler için önem arz etmemekte, çocuklar ve gençler de dâhil olmak üzere toplumun her kesimini ilgilendiren bir konu olmuştur. Finansal konular günümüzde öyle ki çocukları ve gençleri daha fazla ilgilendirmektedir. Çünkü erken dönemde alınan finansal bilgi, davranış ve tutumun önemi yaşamın ileriki dönemlerinde etkili rol oynamaktadır (Gökmen, 2011). Bu nedenle genç nüfusun finansal bilgi düzeyinin artırılması ile hem kaynak kullanım etkinliğinin hem de ekonomik kalkınmışlığın artırılması hedeflenmektedir. Artık 11-20 yaş grubu aralığında olan gençlerimiz de finansal araçları kullanarak bu sisteme dâhil olmakta, acil ve önemli finansal kararlar alma durumu ile karşılaşabilmekte, çoğunlukla da teknolojik altyapısı yeni ve karmaşık olan finansal hizmetlerin hâlihazırda tüketicisi konumunda bulunmaktadırlar (OECD, 2014).

Erken dönem finans eğitiminin finansal davranış ve tutumlardaki olumlu etkisinden dolayı dünya çapında bazı eğitim kurumları müfredatlarında ekonomi ve finans eğitimlerine yer vermeye başlamışlardır. Ülkemizde de bazı özel okullar dünya çapında kabul gören eğitim sistemlerinden biri olan Uluslararası Bakalorya programına göre eğitimlerini vermektedirler. $\mathrm{Bu}$ program yaşam boyu öğrenmeyi teşvik etmekte olup, araştıran-sorgulayan, bilgili, iletişim kabiliyeti yüksek, ilkeli, açık fikirli, sevecen, risk alma kabiliyeti olan ve aynı zamanda dengeli davranışlar sergileyen bireyler yaratmayı amaçlamaktadır (IBO, 2012). Burada eğitim alan öğrenciler 2 yıllık eğitim süresinin bir bölümünde işletme ve ekonomi dersleri almaktadır. Çalışmamızın motivasyon noktasını Uluslararası Bakalorya (IB) eğitimi alan öğrenciler oluşturmaktadır. Çalışmamızdaki amaç, erken dönem ekonomi ve finans eğitiminin bireyin finansal okuryazarlık düzeyi ve finansal davranışları üzerindeki etkisini araştırmaktır. $\mathrm{Bu}$ bağlamda IB eğitimi alan özel okul öğrencileri, IB eğitimi almayan özel okul öğrencileri ve Ticaret Meslek Lisesi öğrencilerinden oluşan 1274 kişilik gruba anket uygulanmıştır. Verilerin analizinde yapısal eşitlik modeli kullanılmıştır.

$\mathrm{Bu}$ çalışma dört bölümden oluşmaktadır. Birinci bölümde Uluslararası Bakalorya Eğitim Programı hakkında tanıtıcı bilgiler verilmiş, ikinci bölümde finansal okuryazarlık ve finansal davranış üzerinde etkisi olan çocukluk dönemi faktörleri hakkında yapılan çalışmalara ilişkin literatür özeti verilmiştir. Üçüncü bölümde araştırmanın modeli ve hipotezler açıklanmış, dördüncü bölümde ise araştırmanın metodolojisi ve analiz sonuçları verilmiştir.

\section{Uluslararası Bakalorya Eğitimi Programı}

Eğitimde ortak programla hareket etmek ve yükseköğrenime geçiş için bir temel başvuru kaynağı oluşturmak için 1924 yılından bu yana uluslararası okulların bir araya gelmeleriyle ortaya çıkan Uluslararası Bakalorya Organizasyonu, 1968 yılında İsviçre'de kurulmuştur. Kar amacı güdülmeyerek oluşturulan bu kuruluşun amac1, orta öğretim ya da yükseköğrenimini kendi ülkesinin dışında sürdüren ve 2-3 yılda bir, başka bir ülkedeki başka okullara geçiş yapan öğrencilerin dâhil oldukları, müfredat programının evrensel ortak bir zemin içerisinde yürütülmesi, gezici genç nüfusa uygun ve uluslararası platformda kabul gören bir üniversite giriş yeterliliği sağlamak olarak belirlenmiştir (Akdoğan, 2014). 
1980“li yılların başından itibaren, Uluslararası Bakalorya okulları, hükümetlerin destek ve teşvikiyle üniversiteler tarafından tanınmaya başlanmıştır. Bazı devletler tarafından ulusal eğitimlerine destek olacak olan bu eğitim sitemini kabul etmeleri zor olmamıștır. IB diploması alan öğrenciler bugün itibari ile Kuzey Amerika, Avustralya, İngiltere ve Avrupa kıtasındaki birçok üniversiteye kabul edilmektedir (IBO, 2012).1994 yılına gelindiğinde 11-16 yaş aralığındaki öğrenciler için orta öğretim programı (MYP) ve 1997 yılında 3-11 yaş aralığındaki öğrenciler için ilköğretim programı (PYP) geliştirilmiştir (IBO, 2012).

Bugün 144 ülkede 3522 okulda DP, MYP ve PYP programlarına 1.078 .000 öğrenci devam etmektedir. Dünya'daki toplam IB Diploma Programı uygulayan okul sayısı 3522'dür. Okulların bazıları her üç programı, bazıları da iki veya sadece birini uygulamaktadır (IBO, 2012). Türkiye'deki üniversiteler IB diploması olan öğrencilere yüzde yüz'e varan oranlarda burs imkânı vermektedir (IBO, 2012). IB diploma programı Türkiye'de 3'ü devlet 45 okulda uygulanmaktadir.

Uluslararası Bakalorya Diploma Programının (IBDP) temelinde altı ders, bir altıgen modeli etrafına dağıtılmıştır. Öğrencilerin iki yıl boyunca bu altı ders grubundan seçilen derslerle beraber bu derslerin merkezinde bulunan, Bitirme Tezi (EE), Bilgi Kuramı (TOK) ve Yaratıcılık-Etkinlik-Sosyal Hizmet (CAS) çalışmalarını başarı ile tamamlamaları gerekmektedir.

\section{Finansal Sosyalizasyon Faktörleri}

Bireylerin finansal yetkinlikleri üzerinde aile yapısı, ebeveyn etkisi, alınan eğitim, sayısal beceri ve para-iş gibi önemli finansal sosyalizasyon faktörlerinin etkisinden bahsetmek mümkündür. Bireysel anlamda geliştirilecek finansal okuryazarlık düzeyi üzerinde etkili olan bu faktörlerle karşılaşılma zamanlaması çok önem arz etmektedir. Çalışmada ele alındığı üzere, finansal okuryazarlık düzeyine etki eden bu faktörlerin, özellikle de erken yaş denilen çocukluk döneminde değerlendirmeye alınması ve takip edilmesi gereklidir.

\section{Aile Geçmişi}

Bireyin çocukluk dönemi üzerinde, hangi davranışla ilgili olursa olsun ailenin etkisi çok önemlidir. Anne ve babanın eğitim seviyesi, ailenin toplam gelir seviyesi, ailede finansal kararları alan kişi, ailenin tasarruf eğilimleri gibi birçok faktörün bireyin finans bilgisi üzerine etkisi olduğu görülmektedir. Aile, özellikle de ebeveynler, gençlerin tasarruf ve paraya yön verme alışkanlığı kazanmasında önemli sosyalleştirme faktörüdür. Lyons, Scherpf, and Roberts (2006) tarafından yapılan çalışmada bir finansal eğitim kursuna katılan lise ve üniversite öğrencilerinin finansal bilgi elde etmek için \%77'sinin ailelerine yöneldikleri tespit edilmiştir. Danes ve Haberman (2007) küçük çocuklar için ailenin, finans öğrenmek için birincil sosyalizasyon aracı olarak var olduğunu savunmuştur. Bunun yanında ailenin, dış dünyadaki bilgiler için bir filtreleme noktası olarak hizmet ederek, çocukların yaşam boyu süren finansal gelişmelerinin temelini oluşturduğunu belirtmişlerdir. Van Rooij, Lusardi, ve Alessie (2011), ise bireylerin finansal konuda bilgi alışverişi için mali danışmanlardan ziyade aile ve arkadaşların yardımına başvurduklarını tespit etmişlerdir. Bireylerin finansal okuryazarlık düzeyine etki eden faktörler üzerinde yapılan çok sayıda çalışmada aile etkisinin büyük bir öneme sahip olduğu tespit edilmiştir (Jorgensen ve Savla, 2010; Lusardi vd., 2010; Lusardi ve Tufano, 2009).

Bazı çalışmalarda finansal karar alımı ve risk tutumlarına ilişkin değişkenler de ebeveynlerin eğitimleri ve aile geçmişi ile ilişkilendirilmiştir. Hryshko vd. (2011), eğitimin zorunlu hale getirilmesinin ebeveynlerin eğitim seviyelerinin artırılmasına ve bununda bu kişilerin daha iyi bir eğitim seviyesi ile daha yüksek risk toleransı aldıklarını iddia etmişlerdir. Başka bir çalışmada Dohmen vd. (2012), risk ve güven gibi tutumların ebeveynlerden çocuklara aktarıldığını ortaya koymuşlardır. Cesarini vd. (2010), tarafından yapılan çalışmada ise finansal kararlarda risk alımının \%25'inin genetik olduğunu iddia etmişlerdir. 


\section{Ebeveynlerin Sunduğu Finansal Sosyalleşme}

Finansal sosyalleşmenin kökleri tüketici sosyalleşmesine dayanır ve gençlerin, piyasadaki tüketiciler olarak işleyişiyle alakalı yetenek, bilgi ve tutumları elde etme süreçleri olarak tanımlanır (Ward, 1974). Danes (1994), ise finansal sosyalleşmeyi, bireyin finansal refahı ve bu refaha katkıda bulunan değerler, tutumlar, standartlar, normlar, bilgi ve davranışların edinilmesi ve geliştirilmesi süreci olarak tanımlamıştır. Aileler, finansal sosyalleşme yoluyla gençlerin finansal davranışlarını geliştirmede kilit bir rol oynayarak, finansal değerleri ve davranışları açıkça ve dolaylı olarak çocuklarına iletirler (Bowen, 2002; John, 1999). Ekonomik toplumsallaşma süreci, aile etkileşimleri ve finansal kaynaklar gibi hane halkı özelliklerinden ve ayrıca çocuğun yaşı ve bilişsel yetenekleri gibi bireysel özelliklerinden de etkilenir (Moschis, 1985). Gudmunson ve Danes (2011), yaptıkları çalışmada, ailelerin, tasarruf etme gibi finansal beceriler geliştirerek gençlerin finansal davranışlarını ve finansal sosyalleşmelerini etkilediklerini belirtmişlerdir. Kim vd. (2015), çocukla alışverişe gitmek ve finans üzerine tartışma yapma gibi ebeveyn eğitimi uygulamalarının, ebeveynlik stiline (ebeveynlerin çocuklarını yetiştirme biçimi) aracılık ettiğini ve bu nedenle de ekonomik sosyalleşmeyi etkilediğini belirlemiş̧lerdir.

\section{Alınan Erken Dönem Ekonomi Eğitimi ve Eğitimin Kalitesi}

Çocuklar ebeveynlerinin finansal çatısı altında olsalar dahi finansal okuryazarlığın yetişkinlerden ziyade çocuklara öğretilmesi, daha sonraki dönemlerde böyle becerileri öğretmenin yerine, çocukların finansal davranışlarının şekillendirilmesine imkân sağlar. Yetişkinler için finansal okuryazarlık eğitimi üzerine bir dizi çalışma olmasına rağmen, böyle bir eğitimin tasarrufların artması gibi finansal davranışları etkilediğine dair sınırlı kanıtlar bulunmaktadır (Fernandes vd., 2014). Yetişkinlere verilen finansal eğitimin kısa vadede bir etkisinin yetersiz kaldığ1 yönünde görüşler ifade edilmiştir. Bunun temel nedeni olarak da finansal kararları şekillendiren bazı alışkanlıkların yetişkinler için değiştirilmesinin zor olmasıdır. Diğer taraftan çocuklara okullar aracılığıyla kolay ulaşılabilme imkânı vardır. Ebeveynleri tarafından, çocuklara tasarruf alışkanlığı kazandırılması ve bu alışkanlığın çocukların finansal davranışlarını olumlu etkilediğine dair kanıtların olması, okul döneminde alınacak finansal eğitimin önemini daha da artırmaktadır (Bucciol ve Veronesi, 2014). Erken dönem ekonomi eğitimin etkinliği hakkında yapılan bazı çalışmalar şöyledir; Schug ve Walstad (1991), ilkokulda alınan finansal eğitimin, öğrencinin olumsuz alışkanlıklarının uzaklaştırılmasına ve okul dışındaki finansal sosyalleşme eksikliğine karşı koymaya yardımcı olduğunu ifade etmişlerdir.

Danes vd. (1999), lise öğrencileri üzerine yapmış oldukları çalışmalarında, lisede öğrencilere uygulanan finansal planlama ile müfredat eğitiminin hemen sonrasında öğrencilerin finansal bilgileri, davranışları ve öz yeterliliklerinin olumlu bir şekilde değiştiğine dair kanıtlar elde etmişlerdir. Walstad vd. (2010), liselerde uygulanan finansal eğitim programlarının ögrencilerin bireysel finans bilgisi üzerindeki etkilerini incelemiş ve alınan müfredat eğitiminin öğrencilerin puanlarını artırdığını bulmuş̧tur. Bruhn vd. (2016), Brezilya'da, finansal eğitim programları ile ilgili, devlet okullarında yürüttükleri çalışmalarında, eğitim programının uygulanmaya başlamasından dört ila on altı ay sonra toplanan verilerle, alınan eğitimin finansal yeterlilik, tasarruf ve bütçeleme gibi kavramlar üzerinde olumlu etkilerinin olduğu sonucuna varmışlardır.

\section{Para ve İş Üzerinden Sağlanan Finansal Sosyalleşme}

Temel eğitimin bitişiyle başlayan, mali bağımlılıktan bağımsızlığa geçiş dönemi çoğu genç yetişkinler için finansal yönetim becerilerinin öğrenilmesi, hayatlarının bu aşamasında temel kalkınma görevlerinden biridir. Öğrendikleri mali davranışların ve bu dönemde oluşturdukları iyi ya da kötü alışkanlıkların hayatlarının geri kalan bölümünde alacakları kararları etkilemesi muhtemeldir. Bireyin yaşantısını etkileyecek bu süreçlerin iyi analiz edilmesi ile eğitimcilerin ve ebeveynlerin gençlere, ekonomik yapılarını daha iyi yönetebilmek 
için ihtiyaç duydukları bilgi ve becerileri kazandırmaya yönelik stratejiler geliştirmelerine yardımc1 olacaktır (Shim vd., 2009).

Juma Ventures, kar amacı gütmeyen bir gençlik geliştirme organizasyonu olup burada gençlere iş becerileri öğretilmiş ve gençlere istihdam olanakları sağlanmıştır. Bu organizasyon 1999 yılında kurulmuş ve gençlere finansal ve tasarruf eğitim içerikli bir program başlatmıştır. $\mathrm{Bu}$ program ile yaklaşık 600 gencin tasarruf hesabı açarak 400.000 bin dolardan fazla tasarruf ettikleri belirtilmiştir (Glod, 2006). Tarihsel olarak sosyologlar, belirli bir takım önemli olayların, bireyin yetişkinlik dönemini etkilediklerini ileri sürmüşlerdir. Bunları; okul eğitiminin bitmesi, tam zamanlı bir işe başlanılması, aileden ayrılma, evlenme ve ebeveyn olma gibi kavramlarla ifade etmişlerdir (Furstenberg v.d., 2005, s.2). Son zamanlarda araştırmacılar, bu rol geçişlerinin zamanlamasının ve sıralamasının değiştiğini keşfetmişlerdir (Furstenberg v.d., 2005, s.3). Bu nedenle bireyin çalışma hayatının hangi yaş aralığına denk geldiği, finansal anlamda iş hayatında hangi tecrübeleri kazandığı, kişinin finansal okuryazarlık durumunun belirleyicisi olan önemli konulardır.

\section{Sayısal Becerilerin Etkisi}

Finansal okuryazar olan bireylerden, doğru ekonomik kararları vermeleri beklenmektedir. Doğru karar doğru bilgi ihtiyacını ortaya çıkarmaktadır. Fakat bilgi bazen tek başına doğru kararın alınması için yeterli olmamaktadır. Burada bireyin o bilgiyi kullanabilme yeteneği diğer bir ifade ile bilişsel yetenekleri de çok önemlidir. Sayısal beceriler bireyin bilişsel yeteneklerinin önemli bir kısmını oluşturur. Aileden, çevreden, okul hayatından ve iş hayatından elde edilen finansal bilgiler, bireyin bilişsel yetenekleri ile daha etkili kararlar haline dönüşebilmektedir. Ghazal vd. (2014), bireyin sayısal becerilerinin finansal okuryazarlığ üzerinde etkilerini araştırdıkları çalışmada, finansal okuryazarlığın üç yönüne yönelik, faiz, enflasyon ve risk çeşitliliği gibi finansal kavramların bilgisini içeren sorular geliştirmişlerdir. $\mathrm{Bu}$ sorulardan ikisinin sayısal yüzdeler ve hesaplama yöntemlerinin sıkı bir şekilde kavranması gerektiğini ifade ederek finansal okuryazarlık yapısının önemli bir kısmının sayısal olarak açıklanabileceğini belirtmişlerdir. Skagerlund vd. (2018), finansal okuryazar olmanın ardındaki itici gücün, sayıları anlamada, matematik ve finansal kararları içeren faaliyetlerdeki, duygusal bir tavır sergileme yeteneğinde olduğunu iddia etmişlerdir. Bunların yanında bilişsel faktörlerin psikolojik etkileri üzerine yapılan çalışmalar da yaygındır. (Dohmen vd., 2019), düşük bilişsel yeteneğe sahip olanların daha sabırsız davranış ve daha fazla riskten kaçınma eğilimi gösterdikleri belirtilmiştir. Korniotis ve Kumar (2010), yaptıkları çalışmada, daha yüksek bilişsel yeteneğe sahip olan yatırımcıların, ticarette daha agresif davrandıklarını öne sürmüşlerdir.

\section{Literatür Araştırması}

Günümüz dünyasında internet teknolojisinin gelişmesi ve medyanın yaygınlaşmasından dolayı, özellikle ilkokul çağındaki çocuklar aktif bir tüketici olmaları için medya tarafından yönlendirilmekte (Suiter ve Meszaros, 2005, s.96), markaları ve farklılıklarını anlayabilmektedir (John, 1999). Bunun yanında ebeveynleri tarafından mali olarak desteklenen çocuklar ise, erken yaşta refah davranışları sergileyerek (Jelks, 2005), tüketim alışkanlıklarını pekiştirmektelerdir. $\mathrm{Bu}$ nedenle araştırmacılar çocukluk dönemini artık finans ve ekonomi dünyasından korunması gereken bir periyot olarak görmemektedir (VanFossen, 2003; Webley vd., 2002). Ayrica, uzmanlar ebeveynlerin çocuklarına tutumlu olmayı teşvik etmesinin, onların finansal kararlar alma konusunda daha dikkatli davrandığını da ileri sürmüşlerdir (Chinadle, 2008; Suiter ve Meszaros, 2005). Finansal yaşamın karmaşıklıkları ve tehlikelerinin tam olarak görüldüğü bu dönem, gençlerin finansal eğitime yönelik meraklarını daha da artırmıştır. Eğitimciler, giderek daha karmaşık hale gelen ekonomik bir ortamda finansal eğitimin, gençlerin, daha sağlam finansal kararlar almasına yardımcı olacağını öne sürmektedir (Lucey ve Giannangelo, 2006). Lusardi ve Mitchell (2014), özellikle orta gelirli ülkelerde finansal okuryazarlık oranının çocuklarda düşük olmasından dolayı finansal eğitimin çocuklar için daha önemli olduğunun 
altını çizmiştir. Yapılan bazı araştırmalarda ilköğretimde alınan finansal eğitimin, öğrencilerin finans alanında yeterliliklerini artırmayı olumlu olarak etkilediğini ve sonraki sınıf seviyelerinde kümülatif anlamda öğrenmeyi destekleyeceğini (Sosin vd., 1997) iddia etmişlerdir.

Yılmaz ve Kaymakçı (2021), lise öğrencilerinin finansal okuryazarlık düzeylerinin finansal davranışları üzerindeki etkilerini araştırdıkları çalışmalarında, gençlerin finansal konularda gösterdikleri davranışların yönlendirilmesinde finansal okuryazarlığın önemli olduğu sonucuna ulaşmışlardır. Yiğitbaş vd. (2020), çalışmalarında, Çanakkale ili Ayvacık ilçesindeki ortaokullarda eğitim gören gençlerde tasarruf bilincinin oluşturulması ve gelecek dönemlerde bu tasarrufları doğru kullanabilmeleri amacıyla bir finansal okuryazarlık eğitimi verildiğini, bu eğitimler sonucunda çocukların ekonomi bilgi, finansal farkındalık düzeylerinin ve güvenlerinin arttığını ifade etmişlerdir. Yücel ve Uysal, (2020), Kırıkkale'de 783 lise öğrencisinin katılımı ile gerçekleştirdikleri araştırmada, lise öğrencilerinin finansal okuryazarlık düzeylerine etki eden faktörleri, anne-baba eğitimi ve anne-babanın finansal bilgi seviyesi, alınan eğitim biçimi ve niteliği olarak ifade etmişlerdir.

Tasarruf alışkanlığının kazandırılması ile ailede başlayan bu eğitim süreci daha sonraki dönemlerde okul eğitimi ile geliştirilip iş hayatında önemli ekonomik kararların alınması ile devam etmektedir. $\mathrm{Bu}$ süreçte finansal okuryazarlık düzeyine etki eden çocukluk dönemi faktörleri önem kazanmaktadır. Grohmann vd. (2015), çocukluk dönemi faktörlerini aile geçmişi, ebeveynlerin sunduğu finansal sosyalleşme, alınan ekonomi eğitimi, eğitimin kalitesi, iş ve para düzeyi üzerinden sağlanan finansal sosyalleşme ve sayısal beceriler olarak sinıflandırmıştır.

\section{Araştırma Modeli ve Hipotezler}

Uluslararası Bakalorya eğitim programı kapsamında bu çalışmaya, alınan ekonomi eğitimi ve eğitimin kalitesi, aritmetik bilgi olarak bireyin bilişsel yeteneği dâhil edilirken aile geçmişi, ebeveynlerin sunduğu finansal sosyalleşme ve para, iş üzerinden sağlanan finansal sosyalleşme değişkenleri de modele bağımsız değişken olarak dâhil edilmiştir. Modelde finansal okuryazarlık değişkeni aracı değişken finansal davranış değişkeni ise bağımlı değişken olarak yer almaktadır. Buradan hareketle araştırmanın modeli aşağıdaki şekilde oluşturulmuştur.

\section{Şekil.1 Araştırma Modeli}

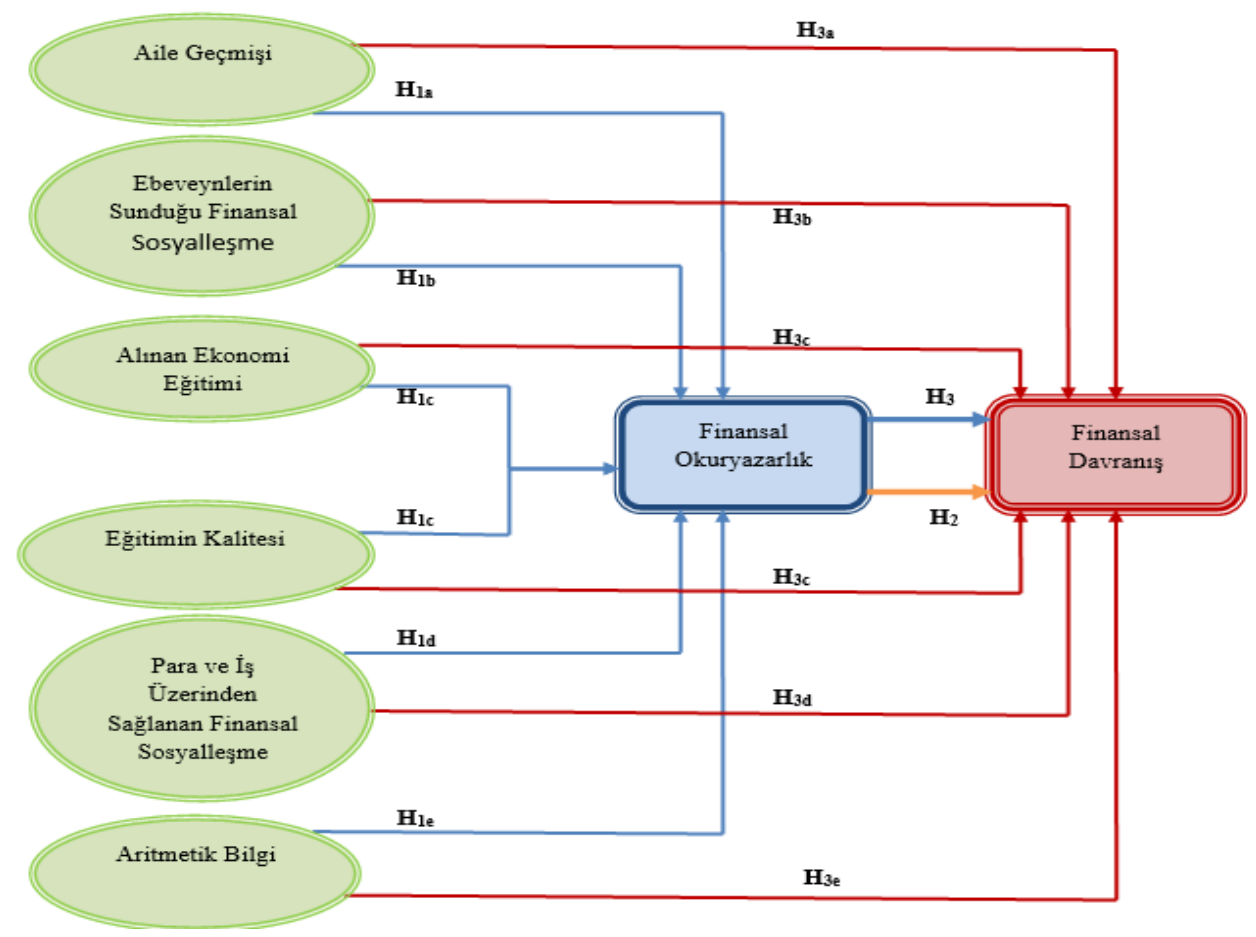


Model üzerinde yer alan bağımsız değişkenlerin finansal okuryazarlık ve finansal davranış üzerindeki etkilerini tespit etmeye yönelik oluşturulan hipotezler aşağıdaki gibidir;

H1 a: Ebeveynlerin finansal okuryazarlık ile ilgili bilgi düzeyleri bireyin finansal okuryazarlığını olumlu etkilemektedir.

$\mathbf{H 1}_{\mathrm{b}}$ : Ebeveynlerce sağlanan finansal sosyalleşme bireyin finansal okuryazarlığını olumlu etkilemektedir.

H1 : Okulda alınan ekonomi eğitimi ve eğitimin kalitesi bireyin finansal okuryazarlığını olumlu etkilemektedir.

H1d: Para ve iş üzerinden sağlanan tecrübe bireyin finansal okuryazarlığını olumlu etkilemektedir.

H1e: Sahip olunan matematiksel beceriler bireyin finansal okuryazarlığını olumlu etkilemektedir.

H2: Bireylerin finansal okuryazarlıkları tasarruf ile ilgili finansal davranışları üzerinde istatistikî olarak anlamlı bir olumlu etkiye sahip olacaktır.

H3a: Aile geçmişi ile finansal davranış ilişkisinde finansal okuryazarlık aracı değişken olarak rol oynayacaktır.

$\mathbf{H 3}_{\mathrm{b}}$ : Ebeveynlerce sağlanan finansal sosyalleşme ile finansal davranış ilişkisinde finansal okuryazarlık aracı değişken olarak rol oynayacaktır.

H3،: Okulda alınan ekonomi eğitimi ve eğitimin kalitesi ile finansal davranış ilişkisinde finansal okuryazarlık aracı değişken olarak rol oynayacaktır.

$\mathbf{H 3}_{\mathrm{d}}$ : Para ve iş üzerinden sağlanan tecrübe ile finansal davranış ilişkisinde finansal okuryazarlık aracı değişken olarak rol oynayacaktır.

H3e: Sahip olunan matematiksel beceri ile finansal davranış ilişkisinde finansal okuryazarlık aracı değişken olarak rol oynayacaktır.

\section{Araştırmanın Amacı ve Metodolojisi}

\subsection{Araștırmanın Amacı}

$\mathrm{Bu}$ araştırmanın amacı, erken dönem ekonomi ve finans eğitiminin bireyin finansal okuryazarlık düzeyi ve finansal davranışları üzerindeki etkisini araştırmaktır. Ayrıca farklı eğitim kurumlarında finansal okuryazarlık ve finansal davranış üzerinde etkili olan çocukluk dönemi faktörlerini belirlemektir.

\section{2. Örneklem ve Yöntem}

Çalışmanın amacına uygun bir sonuç alınabilmesi için, erken yaş dönemi kapsamında $14,15,16,17$ ve 18 yaş grubuna dâhil, lise $9,10,11$ ve 12 . sınıf öğrencileri örneklem grubu olarak seçilmiştir. Trabzon, Ordu, Samsun ve Erzincan'da Uluslararası Bakalorya eğitimi veren özel bir eğitim kurumunda eğitim görmekte olan 419 öğrenci ve IB eğitimi kapsamında eğitim vermeyen bu illerdeki özel okul ve ticaret meslek liselerinde eğitim gören 855 öğrenci olmak üzere toplam 1.274 öğrencilerin tamamına anket uygulaması yapılarak veriler elde edilmiştir. Tanımlayıcı tipteki bu çalışma için, Ondokuz Mayıs Üniversitesi Etik Kurulundan 2018/286 sayılı ve 02/11/2018 tarihli 'Etik Kurul Onayı' alınmıştır.

\subsection{Veri Toplama}

Çalışmada ihtiyaç duyulan verilerin elde edilebilmesi amacıyla, çalışmanın amacına ve konusuna uygun belirli bir özelliği ve niteliği bulunan gruba anket yöntemi uygulanmıştır. Veriler elde edilirken belirlenen gruba üç kez anket uygulaması yapılmıştır. Birinci anket uygulamasından 409 öğrenciden elde edilen verilerle yapılan analizde eksik olduğu 
gözlemlenen finansal davranış ölçeği ankete eklenmiştir. İkinci kez bu defa pilot çalışma olarak 60 öğrenciye anketler uygulanmış ve alınan olumlu sonuçlar ile son olarak 1.274 öğrenciye anket uygulaması yapılarak veriler elde edilmiştir.

Araştırma modeli ile ilişkili olan ve finansal okuryazarlığı ve finansal davranışı etkileyen faktörleri belirleyen ifadeler 5'li likert ölçeği ve evet, hayır, cevap yok, bilmiyorum gibi ifadeler kullanılarak ölçülmüştür. Ankette kullanılan likert ölçeği, "1.Tamamen katılıyorum...5. Kesinlikle katılmıyorum" şeklinde aralıklandırılmıştır. Ankette kullanılan ölçeklerde negatif ifadeli sorular kullanılmamıştır.

Finansal okuryazarlı seviyesinin finansal davranış üzerindeki etkilerinin değerlendirildiği ankette yer alan ifadelerin hazırlanmasında, Grohmann v.d. (2015), Lusardi ve Mitchell (2014), Cole v.d. (2011) ve Güvenç (2015) çalışmalarındaki ölçeklerden faydalanılmıştır.

\section{Analiz ve Bulgular}

\subsection{Analiz}

Erken dönem ekonomi eğitiminin bireyin finansal okuryazarlık seviyesi üzerindeki etkilerinin test edilmesinde yapısal Eşitlik Modeli (YEM) kullanılmıştır. Yapısal eşitlik modellemesi, bir dizi bağımlı değişkenin her biri için ayrı ilişkilere izin veren ve çoklu regresyon denklemlerinin eş zamanlı en etkin tahminini sağlayan bir tekniktir (Hair, Anderson, Tatham, \& William, 1998). Yapısal modelin testini gerçekleştirebilmek amacıyla AMOS 20.0 paket programı kullanılmıştır.

\subsection{Bulgular}

Tablo 1'de örneklem grubuna ait demografik özellikler verilmiş olup, tablo incelendiğinde araştırmaya katılan öğrencilerin \%48,5'ini kadın, \%51,5'ini erkek, \%22,9'unu 15, \%26,9'unu 17 yaş grubu oluştuğu görülmektedir. Öğrencilerin sinıf dağılımlarına bakıldığında \%33,4’ü 10.sinıf, \%20,3’ü 11. sinıf, \%27,4'ü12.sınıf, \%18,8'ide 9. sinıf öğrencilerinden oluşmaktadır.

Tablo 1. Katılımcıların sosyo-demografik dağılımları

\begin{tabular}{|c|c|c|c|c|c|c|c|}
\hline Kategori & Frekans & $\begin{array}{l}\text { Yüzde } \\
(\%)\end{array}$ & $\begin{array}{l}\text { Toplam } \\
\text { Yüzde }\end{array}$ & Kategori & Frekans & $\begin{array}{l}\text { Yüzde } \\
(\%)\end{array}$ & $\begin{array}{l}\text { Toplam } \\
\text { Yüzde }\end{array}$ \\
\hline \multicolumn{4}{|c|}{ Cinsiyet } & \multicolumn{4}{|c|}{ Yaş } \\
\hline Kadın & 618 & 48,5 & 48,5 & 13 yass & 2 & 0,2 & 0,2 \\
\hline Erkek & 656 & 51,5 & 100 & 14 yas & 161 & 12,6 & 12,8 \\
\hline \multicolumn{4}{|c|}{ Sinif } & 15 yaş & 292 & 22,9 & 35,7 \\
\hline 9.sinıf & 239 & 18,8 & 18,8 & 16 yas & 307 & 24,1 & 59,9 \\
\hline 10.sinif & 426 & 33,4 & 52,2 & & 343 & 26,9 & 86,8 \\
\hline 11.sinif & 259 & 20,3 & 72, & 18 & 162 & 12,7 & 99,7 \\
\hline $12 . \sin 1 f$ & 350 & 27,4 & 100 & 19 yaş & 4 & 0,3 & 100 \\
\hline \multicolumn{4}{|c|}{$\begin{array}{c}\text { Babanın Eğitim Durumu (IB Eğitim } \\
\text { Alan Öğrenciler) }\end{array}$} & \multicolumn{4}{|c|}{$\begin{array}{l}\text { Annenin Eğitim Durumu (IB Eğitim } \\
\text { Alan Öğrenciler) }\end{array}$} \\
\hline $\begin{array}{l}\text { Okuryazar } \\
\text { değil }\end{array}$ & 1 & 0,2 & 0,2 & $\begin{array}{l}\text { Okuryazar } \\
\text { değil }\end{array}$ & 18 & 4,3 & 4,3 \\
\hline İlköğretim & 35 & 8,4 & 8,6 & İlköğretim & 98 & 23,4 & 27,8 \\
\hline Lise & 130 & 31 & 39,6 & Lise & 130 & 31,1 & 58,9 \\
\hline Üniversite & 188 & 44,9 & 84,5 & Üniversite & 136 & 32,5 & 91,4 \\
\hline Lisansüstü & 65 & 15,5 & 100 & Lisansüstü & 36 & 8,6 & 100 \\
\hline \multicolumn{4}{|c|}{$\begin{array}{l}\text { Babanın Eğitim Durumu (IB Eğitim } \\
\text { Almayan Özel Okul Öğrencileri) }\end{array}$} & \multicolumn{4}{|c|}{$\begin{array}{l}\text { Annenin Eğitim Durumu (IB Eğitim } \\
\text { Almayan Özel Okul Öğrencileri) }\end{array}$} \\
\hline $\begin{array}{l}\text { Okuryazar } \\
\text { değil }\end{array}$ & 3 & 0 & 0 & $\begin{array}{l}\text { Okuryazar } \\
\text { değil }\end{array}$ & 7 & 6 & 6 \\
\hline İlköğretim & 89 & 21,1 & 21,8 & İlköğretim & 137 & 32,2 & 33,9 \\
\hline
\end{tabular}




\begin{tabular}{cccccccc}
\hline Lise & 159 & 37,7 & 59,5 & Lise & 148 & 34,8 & 68,7 \\
\hline Üniversite & 138 & 32,7 & 92,2 & Üniversite & 114 & 26,8 & 95,5 \\
\hline Lisansüstü & 33 & 7,8 & 100 & Lisansüstü & 19 & 4,5 & 100 \\
\hline $\begin{array}{l}\text { Babanın Eğitim Durumu (IB Eğitim } \\
\text { Almayan Meslek Lisesi Öğrencileri) }\end{array}$ & $\begin{array}{c}\text { Annenin Eğitim Durumu (IB Eğitim } \\
\text { Almayan Meslek Lisesi Öğrencileri) }\end{array}$ \\
$\begin{array}{ccccccc}\text { Okuryazar } \\
\text { değil }\end{array}$ & 6 & 1,4 & 1,4 & $\begin{array}{c}\text { Okuryazar } \\
\text { değil }\end{array}$ & 14 & 3,3 & 3,3 \\
\hline İlköğretim & 239 & 56,2 & 57,6 & İlköğretim & 284 & 66,8 & 70,1 \\
\hline Lise & 155 & 36,5 & 94,1 & Lise & 114 & 26,8 & 96,9 \\
\hline Üniversite & 21 & 4,9 & 99,1 & Üniversite & 12 & 2,8 & 99,8 \\
\hline Lisansüstü & 4 & 0,9 & 100 & Lisansüstü & 1 & 0,2 & 100 \\
\hline
\end{tabular}

Ebeveynlerin eğitim durumunda ise babanın üniversite ve lisansüstü toplam eğitim oranı IB eğitim alan öğrencilerde toplam \%60,4, IB eğitim almayan özel okul öğrencilerinde bu oran $\% 40,5$ ve IB eğitimi almayan meslek lisesi öğrencilerinde ise $\% 5,8$ 'dir. Annenin eğitiminde bu oran IB eğitim alan ögrencilerde toplam \%40,1, IB eğitim almayan özel okul öğrencilerinde bu oran \%31,3 ve IB eğitimi almayan meslek lisesi öğrencilerinde ise \%3'dür.

$\mathrm{Bu}$ çalışmada finansal okuryazarlık düzeyi üzerinde etkili olduğu ortaya konulan faktörlerin araştırılmasına yönelik olarak, güvenirlilik analizi ve doğrulayıcı faktör analizi yapılmıştır. Tablo 2'de çalışma modelinde kullanılan ölçeklerdeki değişken sayıları ile güvenirlik analizi sonuçları verilmiştir.

Tablo 2. Araştırmada yer alan ölçeklerin güvenirlilik analizi sonuçları IB Eğitimi Alan Özel Okul Öğrencileri

\begin{tabular}{|c|c|c|c|}
\hline & & $\begin{array}{c}\text { Değişken } \\
\text { Sayısı }\end{array}$ & $\begin{array}{c}\text { Alfa } \\
\text { KatSayıs }\end{array}$ \\
\hline \multirow{5}{*}{ 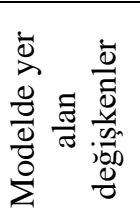 } & Aile geçmişi & 7 & 0,766 \\
\hline & Ebeveynlerin sunduğu finansal sosyalleşme & 7 & 0,702 \\
\hline & Alınan eğitim ve kalitesi & 5 & 0,747 \\
\hline & Para ve iş üzerinden sağlanan finansal sosyalleşme & 3 & 0,724 \\
\hline & Finansal Davranış & 10 & 0,837 \\
\hline \multicolumn{4}{|c|}{ IB Eğitimi Almayan Özel Okul Öğrencileri } \\
\hline \multirow{5}{*}{ 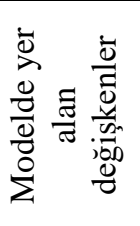 } & Aile geçmişi & 6 & 0,715 \\
\hline & Ebeveynlerin sunduğu finansal sosyalleşme & 8 & 0,705 \\
\hline & Alınan eğitim ve kalitesi & 5 & 0,671 \\
\hline & Para ve iş üzerinden sağlanan finansal sosyalleşme & 4 & 0,773 \\
\hline & Finansal Davranış & 10 & 0,885 \\
\hline \multicolumn{4}{|c|}{ IB Eğitimi Almayan Meslek Lisesi Öğrencileri } \\
\hline \multirow{5}{*}{ 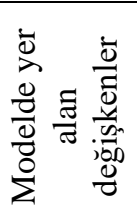 } & Aile geçmişi & 7 & 0,732 \\
\hline & Ebeveynlerin sunduğu finansal sosyalleşme & 8 & 0,719 \\
\hline & Alınan eğitim ve kalitesi & 4 & 0,680 \\
\hline & Para ve iş üzerinden sağlanan finansal sosyalleşme & 4 & 0,726 \\
\hline & Finansal Davranış & 10 & 0,890 \\
\hline
\end{tabular}

Güvenirlik analizine ait Cronbach Alfa katsayıları incelendiğinde "finansal davranış" ölçeğinin \%80'den yüksek olması sebebiyle yüksek derece güvenilir, diğer ölçeklerin tamamının ise $0.60 \leq \alpha<0.80$ aralığında olması nedeniyle oldukça güvenilir olduğu görülmektedir (Kalaycı, 2010).

Tablo 3'de doğrulayıcı faktör analizine ait uyum iyiliği sonuçları verilmiştir. Tablo sonuçlarına bakıldığında $\chi^{2}$ /df, RMSEA, GFI, AGFI, CFI ve NFI değerleri tavsiye edilen ideal uyum ölçütlerini sağladıklarından doğrulayıcı faktör analizi sonucunda ele alınan her bir ölçeğe ait uygun faktör yapısına ulaşıldığg sonucuna varılmaktadır. 
Tablo 3. Doğrulayıcı Faktör Analizi Uyum İyiliği Sonuçları

\begin{tabular}{|c|c|c|c|c|}
\hline \multicolumn{2}{|c|}{ Kabul Edilebilir Uyum Değeri } & $\begin{array}{l}\text { IB Eğitimi } \\
\text { Alan Özel } \\
\text { Okul } \\
\text { Öğrencileri }\end{array}$ & $\begin{array}{c}\text { IB Eğitimi } \\
\text { Almayan } \\
\text { Özel Okul } \\
\text { Öğrencileri }\end{array}$ & $\begin{array}{l}\text { IB Eğitimi } \\
\text { Almayan } \\
\text { Meslek } \\
\text { Lisesi } \\
\text { Öğrencileri }\end{array}$ \\
\hline $\mathrm{X}^{2}$ & $(\mathrm{P}>0,05)$ & $314,63 * * *$ & $449,49 * * *$ & $424,251 * * *$ \\
\hline $\mathrm{X}^{2} / \mathrm{df}$ & $\chi 2 / \mathrm{df} \leq 5$ & 1,597 & 2,071 & 1,928 \\
\hline RMSEA & $0.05<$ RMSEA $<0.10$ & 0,038 & 0,05 & 0,047 \\
\hline GFI & $0.90<\mathrm{GFI}<0.95$ & 0,936 & 0,917 & 0,921 \\
\hline AGFI & $0.80<\mathrm{AGFI}<0.90$ & 0,918 & 0,894 & 0,901 \\
\hline CFI & $0.90<\mathrm{CFI}<0.95$ & 0,947 & 0,883 & 0,897 \\
\hline NFI & $0.90 \leq \mathrm{NFI}<0.95$ & 0,871 & 0,799 & 0,81 \\
\hline
\end{tabular}

\subsection{Yapısal Eșitlik Modeli Analiz Sonuçları}

$\mathrm{Bu}$ araştırmada da literatürde en fazla yer alan uyum iyiliği ölçüleri kullanılmıştır. Tablo 4'de orijinal modelin uyum iyiliği ölçüleri incelendiğinde genel olarak ideal uyum değerlerine uygun olduğu görülmektedir. $\chi 2$ değeri anlamlıdır fakat daha önce de belirtildiği gibi, $\chi 2$ testinin örneklem büyüklügüne duyarlılığı nedeniyle yalnız başına bu değere bakılarak yorum yapılmamalıdır. RMSEA, $\chi 2$ /df değerleri ideal bir uyum değeri taşımaktadırlar. GFI, AGFI ve CFI değerleri kabul edilebilir uyum değerleri arasında yer almaktadırlar. Fakat NFI değeri kabul edilebilir uyum değerlerine yakın değerler olmasına rağmen iyi bir uyum ölçüsü olarak kabul edilmemektedirler.

Tablo 4. Araştırma modelinin uyum iyiliği sonuçları

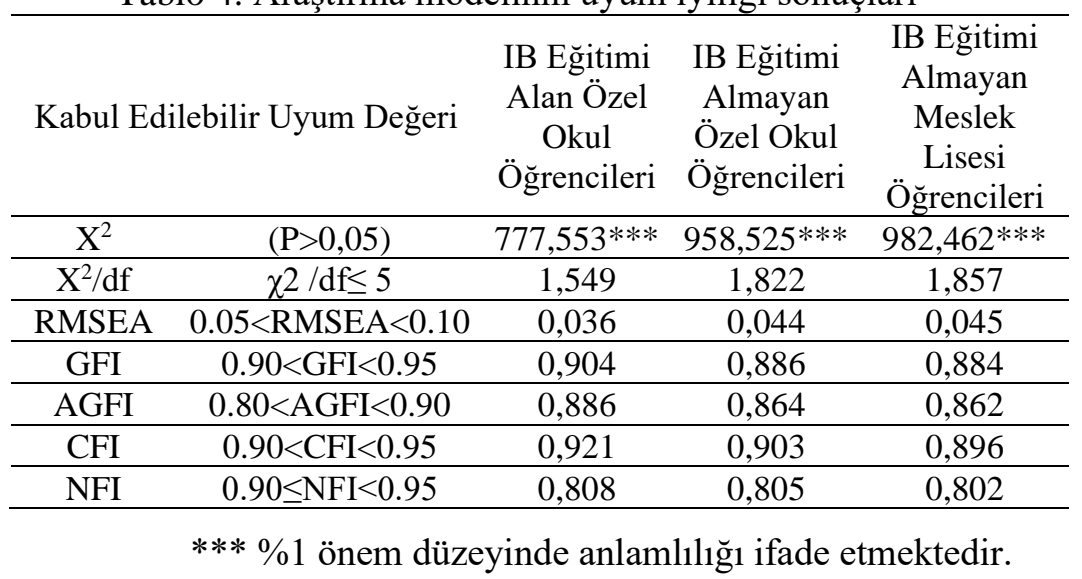

Tablo 5'de Bakalorya eğitimi alan özel okul öğrencilerine ilişkin yapılan yapısal eşitlik modelinin analiz sonuçları verilmiştir. Bu modelde ayrı ayrı finansal okuryazarlık ve finansal davranış düzeyine etki eden çocukluk dönemi faktörleri incelenmiştir. Analiz sonuçlarına bakıldığında IB eğitimi alan öğrencilerin aile geçmişi, aldıkları ekonomi eğitimi ve eğitimin kalitesi, para ve iş üzerinden sağladıkları finansal sosyalleşme ve aritmetik bilgi değişkenlerinin finansal okuryazarlık düzeyi üzerinde pozitif anlamlı bir etkiye sahip olduğu görülmüştür. Bunun yanında ebeveynlerin sunduğu finansal sosyalleşmenin ise finansal okuryazarlık düzeyi üzerinde bir etkisinin olmadığı tespit edilmiştir. Sonuçlara göre finansal okuryazarlık üzerinde standart yol katsayısı en yüksek olan değişkenin 0,217 ile aritmetik bilgi, 0,188 ile ise para ve iş üzerinden sağladıkları finansal sosyalleşme olduğu görülmektedir. 
Tablo 5. IB eğitimi alan özel okul öğrencileriyle elde edilen verilerle oluşturulmuş araştırma modelinin hipotezlerinin değerlendirilmesi

\begin{tabular}{|c|c|c|c|c|c|c|}
\hline $\begin{array}{l}\text { Modeldeki Yapısal } \\
\text { İlişkiler }\end{array}$ & $\begin{array}{l}\text { Std. } \\
\text { Olm. } \\
\text { Yükler }\end{array}$ & $\begin{array}{l}\text { Std. } \\
\text { Olan } \\
\text { Yükler }\end{array}$ & $\begin{array}{l}\text { Std. } \\
\text { Hata }\end{array}$ & $\begin{array}{c}\text { Critical } \\
\text { Ratio } \\
\mathrm{t} \\
\text { değerleri }\end{array}$ & $\begin{array}{l}\text { Olasılık } \\
\text { Değerle } \\
\text { ri }\end{array}$ & $\begin{array}{l}\text { Hipotez } \\
\text { Sonucu }\end{array}$ \\
\hline \multicolumn{7}{|c|}{ Finansal Okuryazarlık Faktörünü Etkileyen Değişkenler } \\
\hline $\begin{array}{l}\mathrm{H}_{1 \mathrm{a}}: \text { Finansal } \\
\text { okuryazarlık } \leftarrow \\
\text { Aile geçmişi }\end{array}$ & 0,436 & 0,136 & $\begin{array}{c}0,18 \\
1\end{array}$ & 2,403 & 0,016 & Kabul \\
\hline $\begin{array}{l}\mathrm{H}_{1 \mathrm{~b}}: \text { Finansal } \\
\text { okuryazarl1k } \leftarrow \\
\text { Ebeveynlerin sun. fin.sos. }\end{array}$ & 0,086 & 0,063 & $\begin{array}{c}0,06 \\
9\end{array}$ & 1,239 & 0,216 & Ret \\
\hline $\begin{array}{l}\mathrm{H}_{1 \mathrm{c}}: \text { Finansal } \\
\text { okuryazarlık } \leftarrow \text { Alınan } \\
\text { eğitim ve kalitesi }\end{array}$ & 0,234 & 0,114 & $\begin{array}{c}0,10 \\
6\end{array}$ & 2,211 & 0,027 & Kabul \\
\hline $\begin{array}{l}\mathrm{H}_{1 \mathrm{~d}} \text { : Finansal } \\
\text { okuryazarlık } \leftarrow \text { Para ve iş } \\
\text { üzer. sağ.fin.sos. }\end{array}$ & 0,476 & 0,188 & $\begin{array}{c}0,13 \\
7\end{array}$ & 3,483 & 0,000 & Kabul \\
\hline $\begin{array}{l}\mathrm{H}_{1 \mathrm{e}}: \text { Finansal } \\
\text { okuryazarlık } \leftarrow \text { Aritmetik } \\
\text { bilgi }\end{array}$ & 0,299 & 0,217 & $\begin{array}{c}0,06 \\
5\end{array}$ & 4,631 & 0,000 & Kabul \\
\hline \multicolumn{7}{|c|}{ Finansal Davranış Faktörünü Etkileyen Değişkenler } \\
\hline $\begin{array}{l}\mathrm{H}_{2}: \text { Finansal davranış } \\
\leftarrow \text { Finansal okuryazarlık }\end{array}$ & 0,048 & 0,114 & $\begin{array}{c}0,03 \\
6\end{array}$ & 2,20 & 0,042 & Kabul \\
\hline $\begin{array}{l}\mathrm{H}_{3 \mathrm{a}}: \text { Finansal davranış } \\
\leftarrow \text { Aile geçmişi }\end{array}$ & 0,033 & 0,022 & $\begin{array}{c}0,09 \\
3 \\
\end{array}$ & 0,355 & 0,722 & Ret \\
\hline $\begin{array}{l}\mathrm{H}_{3 \mathrm{~b}} \text { : Finansal davranış } \\
\leftarrow \text { Ebeveynlerin sun. } \\
\text { fin } \mathrm{coc}\end{array}$ & $-0,017$ & $-0,027$ & $\begin{array}{c}0,03 \\
6 \\
\end{array}$ & $-0,460$ & 0,645 & Ret \\
\hline $\begin{array}{l}\mathrm{H}_{3 \mathrm{c}}: \text { Finansal davranış } \\
\leftarrow \text { Alınan eğitim ve }\end{array}$ & 0,048 & 0,050 & $\begin{array}{c}0,05 \\
6\end{array}$ & 0,857 & 0,392 & Ret \\
\hline $\begin{array}{l}\mathrm{H}_{3 \mathrm{~d}} \text { : Finansal davranış } \\
\leftarrow \text { Para ve iş üzer. }\end{array}$ & $-0,021$ & $-0,018$ & $\begin{array}{c}0,06 \\
9 \\
\end{array}$ & $-0,308$ & 0,758 & Ret \\
\hline $\begin{array}{l}\mathrm{H}_{3 \mathrm{e}}: \text { Finansal davranış } \\
\leftarrow \text { Aritmetik bilgi }\end{array}$ & $-0,011$ & $-0,018$ & $\begin{array}{c}0,03 \\
5\end{array}$ & $-0,327$ & 0,744 & Ret \\
\hline
\end{tabular}

Ayrıca çocukluk dönemi faktörlerinin finansal davranış üzerinde bir etkisinin olmadığ da analiz sonuçlarından anlaşılmaktadır. Fakat finansal okuryazarlığın ise finansal davranış üzerinde 0,114 standart yol katsayısıyla anlamlı ve pozitif bir etkisinin olduğu görülmüştür.

Tablo 7'de IB eğitimi almayan özel okul öğrencilerine ilişkin analiz sonuçları verilmiştir. Tablo incelendiğinde çocukluk dönemi faktörlerinden sadece aritmetik bilgi değişkeninin 0,385 standart yol katsayısıyla finansal okuryazarlık üzerinde pozitif ve anlamlı bir etkisi bulunmuştur. 
Tablo 6. Ib eğitimi almayan özel okul öğrencileriyle elde edilen verilerle oluşturulmuş araştırma modelinin hipotezlerinin değerlendirilmesi

\begin{tabular}{ccccccc}
\hline & Std. & Std. & Critical & Olasılık & Hipotez \\
$\begin{array}{c}\text { Modeldeki Yapısal } \\
\text { İlişkiler }\end{array}$ & Olm. & Olan & Ratio & Rata & t & değerle \\
& Yükler & Yükler & Ha & Sonucu \\
& & & & değerleri & ri & \\
\hline
\end{tabular}

Finansal Okuryazarlık Faktörünü Etkileyen Değişkenler

\begin{tabular}{|c|c|c|c|c|c|c|}
\hline $\begin{array}{l}\mathrm{H}_{1 \mathrm{a}}: \text { Finansal okuryazarlık } \\
\leftarrow \text { Aile geçmişi }\end{array}$ & $-0,178$ & $-0,057$ & 0,228 & $-0,778$ & 0,437 & Ret \\
\hline $\begin{array}{l}\mathrm{H}_{1 \mathrm{~b}} \text { : Finansal okuryazarlık } \\
\leftarrow \text { Ebeveynlerin sun. } \\
\text { fin.sos. }\end{array}$ & $-0,078$ & $-0,023$ & 0,243 & $-0,319$ & 0,750 & Ret \\
\hline $\begin{array}{l}\mathrm{H}_{1 \mathrm{c}} \text { : Finansal okuryazarlık } \\
\leftarrow \text { Alınan eğitim ve } \\
\text { kalitesi }\end{array}$ & $-0,133$ & $-0,067$ & 0,113 & $-1,183$ & 0,237 & Ret \\
\hline $\begin{array}{l}\mathrm{H}_{1 \mathrm{~d}} \text { : Finansal okuryazarlık } \\
\leftarrow \text { Para ve iş üzer. } \\
\text { sağ.fin.sos. }\end{array}$ & 0,121 & 0,053 & 0,115 & 1,056 & 0,291 & Ret \\
\hline $\begin{array}{l}\mathrm{H}_{1 \mathrm{e}} \text { : Finansal okuryazarlık } \\
\leftarrow \text { Aritmetik bilgi }\end{array}$ & 0,362 & 0,385 & 0,042 & 8,538 & 0,000 & Kabul \\
\hline
\end{tabular}

Finansal Davranış Faktörünü Etkileyen Değişkenler

\begin{tabular}{lllllll}
$\begin{array}{l}\mathrm{H}_{2}: \text { Finansal davranış } \\
\leftarrow \text { Finansal okuryazarlık }\end{array}$ & 0,011 & 0,021 & 0,027 & 0,418 & 0,676 & Ret \\
\hline $\begin{array}{l}\mathrm{H}_{3 \mathrm{a}} \text { : Finansal davranış } \\
\leftarrow \text { Aile geçmişi }\end{array}$ & 0,145 & 0,087 & 0,130 & 1,120 & 0,263 & Ret \\
$\begin{array}{l}\mathrm{H}_{3 \mathrm{~b}} \text { : Finansal davranış } \\
\leftarrow \text { Ebeveynlerin sun. }\end{array}$ & 0,521 & 0,294 & 0,153 & 3,407 & 0,000 & Kabul \\
$\begin{array}{l}\mathrm{H}_{3 \mathrm{c}} \text { : Finansal davranış } \\
\leftarrow \text { Alınan eğitim ve }\end{array}$ & 0,241 & 0,227 & 0,067 & 3,568 & 0,000 & Kabul \\
\hline $\begin{array}{l}\mathrm{H}_{3 \mathrm{~d}} \text { : Finansal davranış } \\
\leftarrow \text { Para ve iş üzer. }\end{array}$ & $-0,075$ & $-0,061$ & 0,065 & $-1,154$ & 0,248 & Ret \\
\hline $\begin{array}{l}\mathrm{H}_{3 \mathrm{e}} \text { : Finansal davranış } \\
\leftarrow \text { Aritmetik bilgi }\end{array}$ & 0,010 & 0,021 & 0,026 & 0,406 & 0,685 & Ret
\end{tabular}

Tablo 6'da çocukluk dönemi faktörlerinin finansal davranış üzerindeki etkisine bakıldığında ise ebeveynleri tarafından sağlanan finansal sosyalleşme ile aldıkları eğitim ve kalitesi değişkenlerinin finansal davranış üzerinde sırasıyla 0,294 ve 0,227 standart yol katsayıları ile pozitif ve anlamlı bir etkisinin olduğu tespit edilmiştir.

Tablo 7'de Bakalorya eğitimi almayan meslek lisesi öğrencilerine ilişkin yapılan yapısal eşitlik modelinin analiz sonuçları verilmiştir. Bu modelde de finansal okuryazarlık ve finansal davranış düzeyine etki eden çocukluk dönemi faktörleri incelenmiştir. 
Tablo 7. Ib eğitimi almayan meslek lisesi öğrencileriyle elde edilen verilerle oluşturulmuş araştırma modelinin hipotezlerinin değerlendirilmesi

\begin{tabular}{|c|c|c|c|c|c|c|}
\hline Modeldeki Yapısal İlişkiler & $\begin{array}{l}\text { Std. } \\
\text { Olm. } \\
\text { Yükler }\end{array}$ & $\begin{array}{l}\text { Std. } \\
\text { Olan } \\
\text { Yükler }\end{array}$ & $\begin{array}{l}\text { Std. } \\
\text { Hata }\end{array}$ & $\begin{array}{c}\text { Critical } \\
\text { Ratio } \\
\mathrm{t} \\
\text { değerleri } \\
\end{array}$ & $\begin{array}{l}\text { Olasılık } \\
\text { değerleri }\end{array}$ & $\begin{array}{l}\text { Hipote } \\
\quad \mathrm{z} \\
\text { Sonucu }\end{array}$ \\
\hline \multicolumn{7}{|c|}{ Finansal Okuryazarlık Faktörünü Etkileyen Değişkenler } \\
\hline $\begin{array}{l}\mathrm{H}_{1 \mathrm{a}} \text { :Finansal okuryazarlık } \\
\leftarrow \text { Aile geçmişi }\end{array}$ & $-0,484$ & $-0,171$ & 0,508 & $-0,954$ & 0,340 & Ret \\
\hline $\begin{array}{l}\mathrm{H}_{1 \mathrm{~b}} \text { : Finansal } \\
\text { okuryazarlık } \leftarrow \\
\text { Ebeveynlerin sun. fin.sos. }\end{array}$ & 0,113 & 0,034 & 0,663 & 0,171 & 0,864 & Ret \\
\hline $\begin{array}{l}\mathrm{H}_{1 \mathrm{c}}: \text { Finansal } \\
\text { okuryazarlık } \leftarrow \text { Alınan } \\
\text { eğitim ve kalitesi }\end{array}$ & $-0,077$ & $-0,025$ & 0,249 & $-0,309$ & 0,758 & Ret \\
\hline $\begin{array}{l}\mathrm{H}_{1 \mathrm{~d}}: \text { Finansal } \\
\text { okuryazarlık } \leftarrow \text { Para ve iş }\end{array}$ & $-0,037$ & $-0,017$ & 0,118 & $-0,311$ & 0,756 & Ret \\
\hline $\begin{array}{l}\mathrm{H}_{1 \mathrm{e}}: \text { Finansal } \\
\text { okuryazarlik } \leftarrow \text { Aritmetik }\end{array}$ & 0,247 & 0,302 & 0,043 & 5,786 & 0,000 & Kabul \\
\hline \multicolumn{7}{|c|}{ Finansal Davranış Faktörünü Etkileyen Değişkenler } \\
\hline $\begin{array}{l}\mathrm{H}_{2} \text { :Finansal davranış } \\
\leftarrow \text { Finansal okuryazarlık }\end{array}$ & 0,028 & 0,052 & 0,026 & 1,047 & 0,295 & Ret \\
\hline $\begin{array}{l}\mathrm{H}_{33} \text { : Finansal davranış } \\
\leftarrow \text { Aile geçmişi }\end{array}$ & $-0,057$ & $-0,038$ & 0,274 & $-0,208$ & 0,835 & Ret \\
\hline $\begin{array}{l}\mathrm{H}_{3 b} \text { : Finansal davranış } \\
\leftarrow \text { Ebeveynlerin sun. }\end{array}$ & 0,689 & 0,390 & 0,369 & 1,867 & 0,062 & Ret \\
\hline $\begin{array}{l}\mathrm{H}_{3 \mathrm{c}} \text { : Finansal davranış } \\
\leftarrow \text { Alınan eğitim ve }\end{array}$ & $-0,032$ & $-0,028$ & 0,063 & $-0,504$ & 0,614 & Ret \\
\hline $\begin{array}{l}\mathrm{H}_{3 \mathrm{~d}} \text { : Finansal davranış } \\
\leftarrow \text { Para ve iș üzer. }\end{array}$ & 0,441 & 0,275 & 0,146 & 3,022 & 0,003 & Kabul \\
\hline $\begin{array}{l}\mathrm{H}_{3 \mathrm{e}} \text { : Finansal davranış } \\
\leftarrow \text { Aritmetik bilgi }\end{array}$ & 0,009 & 0,021 & 0,023 & 0,381 & 0,703 & Ret \\
\hline
\end{tabular}

Tablo 7'deki bulgular incelendiğinde, IB eğitimi almayan meslek lisesi öğrencilerinin finansal okuryazarlık düzeyi üzerinde aritmetik bilgi değişkeninin 0,302 standart yol katsayısıyla pozitif ve anlamlı bir etkisi olduğu tespit edilmiştir. Tablo sonuçlarından çocukluk dönemi faktörlerinin finansal davranış üzerindeki etkisine bakıldığında ise sadece para ve iş üzerinden sağladıkları finansal sosyalleşme değişkeninin 0,275 standart yol katsayısı ile finansal davranış üzerinde pozitif bir etkiye sahip olduğu gözlenmiştir. Öğrencilerin finansal okuryazarlıkların ise finansal davranışları üzerinde anlamlı bir etkiye sahip olduğu görülmektedir.

\section{Sonuç ve Öneriler}

İlkokuldan başlayan üniversite dönemi ile biten eğitim hayatı içerisinde öğrenilen bilgilerin bireye yol gösterici olabilmesi için bu bilgilerin somutlaştırılması gerekmektedir. Dolayısıyla ilköğretim çağında olan bir çocuğun bu imkânlara sahip olabilmesi zor göründüğünden, bilginin uygulamaya, davranışa dönüştürülmesi yani fikir yaratma, rol model olma adına ailelere özellikle de ebeveynlere çok büyük görevler düşmektedir. Bunun yanında finansal eğitim anlamında Millî Eğitim Bakanlığı tarafından oluşturulmuş ders müfredatının temele yayılarak erken yaş dönemi denilen, ilköğretimden başlamak kaydıyla bu eğitimlerin ivedilikle müfredatlara eklenmesi ve ailelerle ortak çalışlarak bu eğitimlerin çocuk üzerindeki 
etkilerinin artırılması gerekmektedir. Eğitim sistemi içerisinde yer alan devlet okulları dışında özel eğitim veren bazı eğitim kuruluşları bu eksikliğin farkına vararak, birazda farklılık yaratma ihtiyacından kaynaklı, finans içerikli eğitimleri ders müfredatlarında işlemektedirler. Çalışmanın temel yaklaşımlarından birisi olan, bu tip bir eğitim sistemini bünyesinde barındıran ve Uluslararası Bakalorya (IB) Diploma Programını uygulayan ve uygulamayan hem özel hem de devlet okullarında eğitim alan lise öğrencilerinin finansal okuryazarlık seviyeleri ve finansal davranış biçimleri incelenmiştir.

Ekonomik kazanım, sadece maddi varlık olan paranın kazanılması anlamına gelmemelidir. Tasarruf alışkanlığı, planlama, riskten kaçınma ve yatırım gibi birçok davranışı da ifade etmektedir. Burada temel ve hayati görev ailelere, ebeveynlere düşmektedir. Ebeveynler hem davranışları ile hem de yönlendirmeleriyle bu kazanımları daha anlamlı hale getirebilirler. Örneğin, maddi gücü yerinde olan bir ailenin çocuğunu ihtiyacı olduğu için değil de finansal alışkanlıkları kazanabilmesi için, eğitim öğretim dönemleri dışında uygun işlerde çalıştırması çocuğa ve onun geleceği adına büyük kazanımlar sağlayacaktır.

Doğru finansal davranışın oluşturulması açısından, ebeveynlerin çocuklarına finansal bilgiyi aktardıklarını fakat bu bilginin uygulamaya dönüştürülmesinde yeterli firsatın verilmediğini söyleyebiliriz. Dolayısıyla ebeveynler tarafından sağlanan finansal sosyalleşmenin bireyin finansal okuryazarlığ üzerinde olumlu ve anlamlı bir etki yaratabilmesi için anne ve babalar tarafından alınan ekonomik kararlara ve davranışlara çocukların fiili olarak katılımlarının sağlanması gerekmektedir.

Erken dönemde alınacak ekonomi-finans eğitiminin ve bu eğitimin kalitesinin, ekonomik kavramların öğrenilmesi, algılanması ve doğru finansal davranışa dönüştürülmesi bireyin finansal okuryazarlık seviyesi üzerinde anlamlı bir fayda oluşturmaktadır. Bu doğrultuda Uluslararası Bakalorya (IB) eğitimi olarak adlandırılan, temel eğitim kapsamında hazırlanmış eğitim müfredatının bu programı uygulamayan diğer eğitim kurumlarında da uygulamaya alınması finansal okuryazarlık kavramının erken yaşlarda daha iyi algılanmasına ve anlaşılmasına yol açacaktır. Analiz sonucunda, alınan ekonomi içerikli eğitimler ve bu eğitimlerin kalitesi bireyin finansal okuryazarlık seviyesini olumlu yönde artırmaktadır.

$\mathrm{Bu}$ çalışmada, Uluslararası Bakalorya eğitim programı çerçevesinde erken dönem denilen çocukluk dönemini kapsayacak şekilde bireyin ekonomi ve finans eğitimi almasının finansal okuryazarlık seviyesi üzerinde olumlu etki yarattığı, finansal davranışları üzerinde ise bir etkisinin olmadığı sonucuna varılmıştır. Diğer taraftan finansal okuryazarlık seviyesi üzerinde sadece eğitimin etkili olmadığı, eğitim dışında da aile geçmişinin, ebeveynlerin sağladığı finansal sosyalleşmenin ve çalışılarak kazanılan paranın etkisinin olduğunu ifade etmek gerekir.

Sonuç olarak, çalışmanın hipotez sonuçlarına bakıldığında bilişsel zekanın finansal okuryazarlık üzerinde etkili olduğu görülmektedir. Okullarda verilen sayısal eğitim hem bireylerin bilişsel zekalarının gelişmesine hem de gelecek adına bireylerin günlük ticari işlemlerinin doğru yürütülmesine fayda sağlayacaktır. Son olarak bireye eğitimle ve sosyalleşme ile kazandırılan finansal okuryazarlık sıfatının anlamlı, doğru ve akılcı finansal davranışlara dönüştürülebilmesi için erken yaş döneminde ebeveynleri tarafından çocukların, çalışarak para kazanma alışkanlarını elde etmeleri sağlanmalıdır.

\section{Kaynakça}

Akdoğan, A. (2014), "Türkiye'deki Uluslararası Bakalorya Pyp programı uygulayan okulların etkili okul özellikleri ve okul kültürü açısından incelenmesi", (Yayınlanmamış doktora tezi). İstanbul Üniversitesi, Eğitim Bilimleri Enstitüsü.

Bowen, C. F. (2002), "Financial knowledge of teens and their parents", Financial Counseling and Planning, 13(2), 93-102. 
Bruhn, M., Leão, L. d. S., Legovini, A., Marchetti, R. and Zia, B. (2016), "The impact of high school financial education: Evidence from a large-scale evaluation in Brazil", American Economic Journal: Applied Economics, 8(4), 256-295.

Bucciol, A. and Veronesi, M. (2014), "Teaching children to save and lifetime savings: What is the best strategy", Journal of Economics Psychology, 45, 1-17.

Cesarini, D., Johannesson, M., Lichtenstein, P., Sandewall, Ö. and Wallace, B. (2010), "Genetic variation in financial decision making", The journal of finance, 65(5), 1725-1754.

Chinadle, N. (2008), "Lucey, TA, \& Cooter, KS (eds), Financial Literacy for Children and Youth", In: Springer.

Danes, S. M. (1994), "Parental perceptions of children's financial socialization", Financial Counseling and Planning, 5(1), 27-149.

Danes, S. M. and Haberman, H. (2007), "Teen financial knowledge, self-efficacy, and behavior: A gendered view", Journal of Financial Counseling and Planning, 18 (2).

Danes, S. M., Huddleston-Casas, C. and Boyce, L. (1999), "Financial planning curriculum for teens: Impact evaluation", Journal of Financial Counseling and Planning, 10(1), 26.

Dohmen, T., Falk, A., Huffman, D. and Sunde, U. (2012), "The intergenerational transmission of risk and trust attitudes" The Review of Economic Studies, 79(2), 645-677.

Dohmen, T., Falk, A., Huffman, D. and Sunde, U. (2019), "Replication data for: Are Risk Aversion and Impatience Related to Cognitive Ability?"

Fernandes, D., Lynch Jr, J. G. and Netemeyer, R. G. (2014), "Financial literacy, financial education, and downstream financial behaviors", Management Science, 60(8), 1861-1883.

Glod, M. (2006), "Schools bank on teaching kids how to save" The Washington Post.

Gökmen, H. (2011), "Finansal okuryazarlık" , (43): Hiperlink eğit. ilet. yay. san. tic. ve ltd. sti.

Grohmann, A., Kouwenberg, R. and Menkhoff, L. (2015), "Childhood roots of financial literacy"., Journal of Economic Psychology, 51,114-133.

Gudmunson, C. G. and Danes, S. M. (2011), "Family financial socialization: Theory and critical review", Journal of Family and Economic Issues, 32(4), 644-667.

Hair, J. F., Anderson, R. E., Tatham, R. L. and William, C. (1998), "Black (1998), Multivariate data analysis", In: Upper Saddle River, NJ: Prentice Hall.

Hryshko, D., Luengo-Prado, M. J. and Sorensen, B. E. (2011), "Childhood determinants of risk aversion: The long shadow of compulsory education", Quantitative Economics, 2(1), 37-72.

Ibo. (2012), "Developing a transdisciplinary programme of inquiry", Cardif, Wales, UK.: International Baccalaureate Peterson House

Jelks, M. G. (2005), "Premature affluence: Factors related to excessive teen spending", University of Georgia,

John, D. R. (1999), "Consumer socialization of children: A retrospective look at twenty-five years of research", Journal of consumer research, 26(3),183-213.

Jorgensen, B. L. and Savla, J. (2010), "Financial literacy of young adults: The importance of parental socialization", Family relations, 59(4), 465-478.

Kalaycı, Ş. (2010), "SPSS uygulamalı çok değişkenli istatistik teknikleri",(5): Asil Yayın Dağıtım Ankara, Turkey. 
Kim, C., Yang, Z. and Lee, H. (2015), "Parental style, parental practices, and socialization outcomes: An investigation of their linkages in the consumer socialization context", Journal of Economic Psychology, 49, 15-33.

Kornıotis, G. M. and Kumar, A. (2010), "Cognitive abilities and financial decisions", Behavioral Finance, 559-576.

Lucey, T. A. and Giannangelo, D. M. (2006), "Short changed: The importance of facilitating equitable financial education in urban society", Education and urban society, 38(3), 268287.

Lusardi, A. and Mitchell, O. S. (2011), "Financial literacy and planning: Implications for retirement wellbeing". Retrieved from

Lusardi, A., Mitchell, O. S. and Curto, V. (2010), "Financial literacy among the young", Journal of Consumer Affairs, 44(2), 358-380.

Lusardi, A. and Tufano, P. (2009), "Debt Literacy. Financial Experience and Overindebtedness", Dartmouth College and Harvard Business School Working Paper.

Lyons, A. C., Scherpf, E. and Roberts, H. (2006), "Financial education and communication between parents and children", The Journal of Consumer Education, 23(2006), 64-76.

Moschis, G. P. (1985), "The role of family communication in consumer socialization of children and adolescents", Journal of consumer research, 11(4), 898-913.

Oecd. (2014), "PISA 2012 results: Students and money: Financial literacy skills for the 21st century".

Schug, M. and Walstad, W. (1991), "Teaching and learning economics", Handbook of research on social studies teaching and learning, 411-419.

Shim, S., Xiao, J. J., Barber, B. L. and Lyons, A. C. (2009), "Pathways to life success: A conceptual model of financial well-being for young adults", Journal of Applied Developmental Psychology, 30(6), 708-723.

Skagerlund, K., Lind, T., Strömbäck, C., Tinghög, G. and Västfjäll, D. (2018), "Financial literacy and the role of numeracy-How individuals' attitude and affinity with numbers influence financial literacy", Journal of Behavioral and Experimental Economics, 74, 18-25.

Sosin, K., Dick, J. and Reiser, M. L. (1997), "Determinants of achievement of economics concepts by elementary school students", The Journal of Economic Education, 28(2), 100121.

Suiter, M. and Meszaros, B. (2005), "Teaching about saving and investing in the elementary and middle school grades", Social Education, 69(2), 92-95.

Van Rooij, M., Lusardi, A. and Alessie, R. (2011), "Financial literacy and stock market participation", Journal of Financial economics, 101(2), 449-472.

Vanfossen, P. J. (2003), "Best practice economic education for young children? It's elementary! Kickball or four-square at recess? Pack lunch or buy it? Spend Aunt Edna's $\$ 10$ birthday check or save it for a larger gift in the future? Do math homework or play soccer after school?(Raising It In Economics)",Social Education, 67(2), 90-95.

Walstad, W. B., Rebeck, K. and Macdonald, R. A. (2010), "The effects of financial education on the financial knowledge of high school students", Journal of Consumer Affairs, 44(2), 336-357.

Ward, S. (1974), "Consumer socialization", Journal of consumer research, 1(2), 1-14. 
Webley, P., Burgoyne, C., Lea, S. and Young, B. (2002), "The economic psychology of everyday life": Psychology Press.

Xu, L. and Zia, B. (2012), "Financial literacy around the world: an overview of the evidence with practical suggestions for the way forward", The World Bank.

Yılmaz, H., and Kaymakçı, T. (2021), "Finansal Davranışlar Ve Finansal Okuryazarlık İlişkisi”, Akademik Hassasiyetler, 8(15), 141-164.

Yiğitbaş, Ş., Temeloğlu, E. and Şimşek, A. (2020). "Ortaöğretim Çağındaki Gençlerde Finansal Eğitimin Finansal Okuryazarlık Üzerindeki Etkisi”, IBAD Sosyal Bilimler Dergisi, 411-432.

Yücel, K. O. and Uysal, B. (2020). "Kırıkkale'deki lise öğrencilerinin finansal okuryazarlık düzeyinin belirlenmesine yönelik bir araştırma", Işsletme Akademisi Dergisi, 1(4), 344-363.

\section{ETIKK ve BİLIMSEL İLKELER SORUMLULUK BEYANI}

$\mathrm{Bu}$ çalışmanın tüm hazırlanma süreçlerinde etik kurallara ve bilimsel atıf gösterme ilkelerine riayet edildiğini yazar(lar) beyan eder. Aksi bir durumun tespiti halinde Afyon Kocatepe Üniversitesi Sosyal Bilimler Dergisi'nin hiçbir sorumluluğu olmayıp, tüm sorumluluk makale yazarlarına aittir. Yazarlar etik kurul izni gerektiren çalışmalarda, izinle ilgili bilgileri (kurul adı, tarih ve sayı no) yöntem bölümünde ve ayrıca burada belirtmişlerdir.

Kurul adı: Ondokuz Mayıs Üniversitesi Sosyal ve Beşerî Bilimler Etik Kurulu

Tarih:02.11.2018

No: 9

\section{ARAŞTIRMACILARIN MAKALEYE KATKI ORANI BEYANI}

1. yazar katk1 oranı : $\% 50$

2. yazar katk1 oran1 : $\% 50$ 